\title{
Influence of temperature, habitat and body mass on routine metabolic rates of Subantarctic teleosts*
}

\author{
FABIÁN ALBERTO VANELLA and JORGE CALVO \\ Centro Austral de Investigaciones Científicas (CADIC), CC 92 (9410), Ushuaia, Argentina. \\ E-mail: fvanella@tierradelfuego.org.ar
}

\begin{abstract}
SUMMARY: Subantarctic notothenioids are exposed to wider variations in temperature than those encountered in the Antarctic Ocean, the ancestral environment of the group. In this study the influence of temperature on the routine metabolic rate of Subantarctic teleosts was described and the results were compared with routine metabolic rates of species with different geographical distributions, exploring the concept of Metabolic Cold Adaptation (MCA). Oxygen consumption $\left(\mathrm{VO}_{2 \mathrm{R}}\right)$ was determined as an estimate of the routine metabolic rate for the following Subantarctic notothenioids: Paranotothenia magellanica, Patagonotothen sima, Eleginops maclovinus, Harpagifer bispinis and the eelpout Austrolycus depressiceps. In all studied species and tested temperatures, body mass and $\mathrm{VO}_{2 \mathrm{R}}$ showed a positive correlation. A drop in the temperature from 10 to $2^{\circ} \mathrm{C}$ produced a significant reduction of $\mathrm{VO}_{2 \mathrm{R}}$ values with a $\mathrm{Q}_{10(10-2)}$ varying between 4.69 and 9.54. $\mathrm{VO}_{2 \mathrm{R}}$ values were related to species habitat: pelagic species reached the highest values of $\mathrm{VO}_{2 \mathrm{R}}$, while sluggish species had the lowest ones. We can conclude that the metabolic rates of these species of Subantarctic fish do not show MCA at the investigated temperatures.
\end{abstract}

Keywords: metabolic cold adaptation, Subantarctic fish, notothenioids, respirometry, temperature.

RESUMEN: INFLUENCIA DE LA TEMPERATURA, HÁBITAT Y MASA CORPORAL EN LA TASA METABÓLICA DE RUTINA DE TELEÓSTEOS SUBANTÁRTICOS. - Los nototénidos subantárticos se encuentran expuestos a mayores variaciones de temperatura que las del Océano Antártico, el ambiente ancestral del grupo. En este estudio, se describe la influencia de la temperatura en la tasa metabólica de rutina de teleósteos subantárticos. Los resultados fueron comparados con tasas metabólicas de rutina de especies con diferente distribución geográfica, explorando el concepto de Adaptación Metabólica al Frío (AMF). Se determinó el consumo de oxígeno $\left(\mathrm{VO}_{2 \mathrm{R}}\right)$ como una estimación de la tasa metabólica de rutina para las siguientes especies de nototénidos subantárticos: Paranotothenia magellanica, Patagonotothen sima, Eleginops maclovinus, Harpagifer bispinis y el Zoarcidae Austrolycus depressiceps. La masa del cuerpo y la $\mathrm{VO}_{2 \mathrm{R}}$ mostraron una correlación positiva en todas las especies estudiadas y temperaturas experimentales. Una disminución de la temperatura de 10 a $2^{\circ} \mathrm{C}$ produjo una reducción significativa de los valores de $\mathrm{VO}_{2 \mathrm{R}}$, con un $\mathrm{Q}_{10(10-2)}$ que varió entre 4,69 y 9,54. Los valores de $\mathrm{VO}_{2 \mathrm{R}}$ estuvieron correlacionados con el hábitat particular de cada especie. Las especies pelágicas alcanzaron los valores más altos, mientras que las especies poco activas tuvieron los más bajos. Podemos concluir que la tasa metabólica de estos peces subantárticos no presenta AMF a las temperaturas ensayadas.

Palabras clave: adaptación metabólica al frío, peces subantárticos, nototenioideos, respirometría, temperatura.

\section{INTRODUCTION}

The hypothesis of Metabolic Cold Adaptation (MCA) predicts a higher metabolic rate than that expected by extrapolation of data from warmer

*Received June 24, 2004. Accepted May 11, 2005. water species. Since this was started by Krogh (1916), followed by Scholander (1953) and Wohlschlag (1960), the Metabolic Cold Adaptation (MCA) theory has gained support among some authors (Torres and Somero, 1988a, b; Crockett and Sidell, 1990; Pörtner et al., 2000; Pörtner, 2002), and generated disagreement among others (Holeton, 


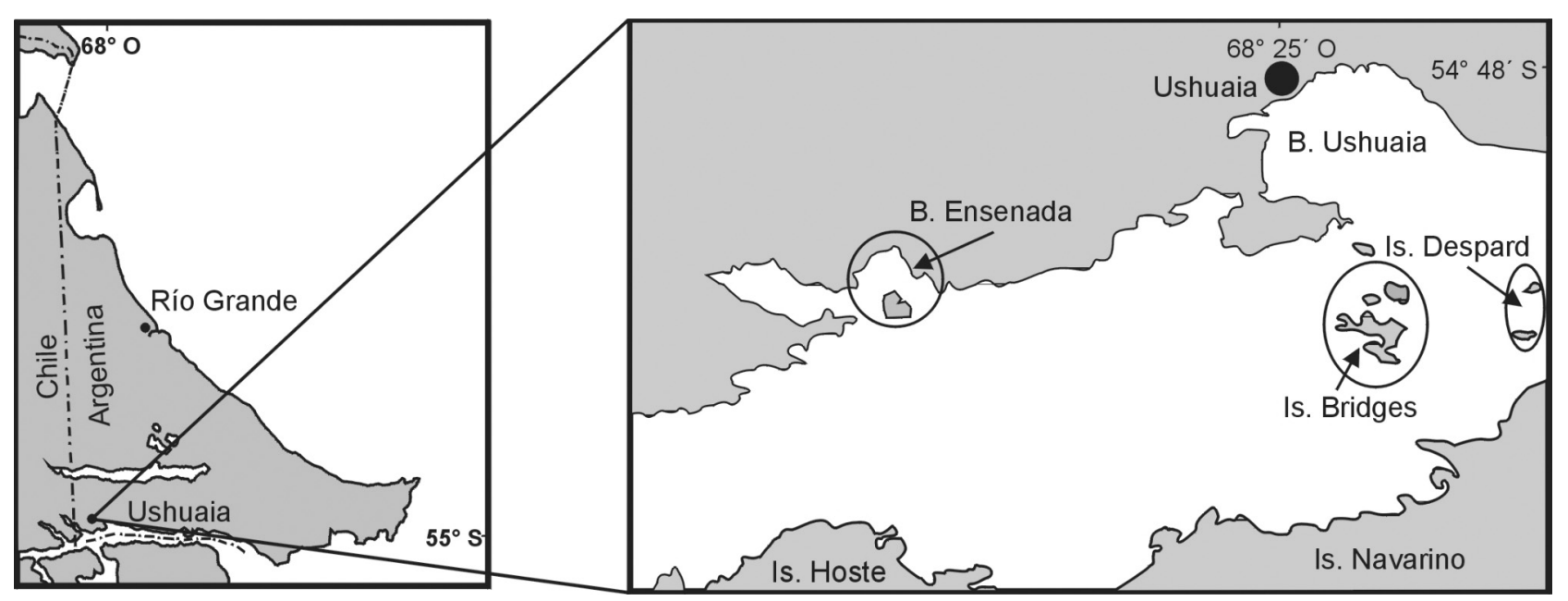

FIG. 1. - Geographical reference of the sampling area (in dark grey). Ushuaia Bay, Despard Is, Bridges Is. and Ensenada Bay.

1974; Steffensen et al., 1994; Steffensen, 2002). As a valid method, Somero (1991) suggested a comparison between species belonging to the same genus or family. Clarke and Johnston (1999) emphasised the value of comparisons between Antarctic notothenioids and perciforms of warmer waters. Remarkably, Clarke (1991) proposed initially an approach at cellular level to contribute to the discussion on MCA and temperature compensation.

Metabolism of Antarctic and Arctic poikilotherms has been under review, in the search for a deeper understanding of the influence of body size, life style and temperature on metabolic activity. These aspects vary according to the evolutionary history of each species and the individual thermal record (Peck, 2002; Sidell, 2000).

Scaling is the structural and functional consequence of changes in body size or scale among otherwise similar organisms (Schmidt-Nielsen, 1984). For fishes, this correlation has been fairly well demonstrated (Clarke and Johnston, 1999; Willmer et al., 2000).

Oxygen consumption rate was found to be correlated with the habitat for Arctic and Antarctic fishes (Morris and North,1984; Zimmermann, 1997).

Subantarctic notothenioids are exposed to a wider variation in temperature than those encountered in the Southern Ocean, making this group well suited to perform comparative analyses. However, only few data are available on their metabolic aspects (Johnston et al., 1998).

The aims of this study are to investigate the influence of temperature, habitat and body mass on the routine metabolic rate of Subantarctic teleosts, and to compare the results with routine metabolic rates of species with different geographical distrib- utions, exploring the concept of Metabolic Cold Adaptation (MCA).

\section{MATERIAL AND METHODS}

\section{Samples}

The adults or juvenile fish used in this study were captured by hand, trammel nets or seine around the area of Bahía Ushuaia (Tierra del Fuego, Argentina) and its vicinity in summer, from 1999 to 2003 (Fig. 1). Water temperature ranged from 4 to $10^{\circ} \mathrm{C}$ in winter and summer respectively.

The following species were used in this study: Nototheniidae: Paranotothenia magellanica (Hutton, 1875; capture technique, trammel net; depth, 10 m); Patagonotothen sima (Richardson, 1845; Capture technique, trap; depth, 0-5 m). Eleginopidae: Eleginops maclovinus (Valenciennes, 1830; Capture technique, seine; depth, 0-1 m), Harpagiferidae: Harpagifer bispinis (Schneider, 1801; capture technique, hand; depth, intertidal zone), Zoarcidae: Austrolycus depressiceps (Regan, 1913; capture technique, hand; depth, intertidal zone). The standard

TABLE 1. - Habitat and physical characteristics of species which were studied in the present work. $\pm=$ standard deviation.

\begin{tabular}{|c|c|c|c|}
\hline Species & Habitat & $\begin{array}{l}\text { Standard Length } \\
(\mathrm{LS} \mathrm{mm})\end{array}$ & $\begin{array}{l}\text { Body Mass } \\
\text { (M g) }\end{array}$ \\
\hline P. magellanica & Pelagic & $202 \pm 32$ & $126.87 \pm 64.63$ \\
\hline$P$. sima & Benthopelagic & $117 \pm 11$ & $27.35 \pm 7.14$ \\
\hline E. maclovinus & Benthopelagic & $97 \pm 36$ & $14.29 \pm 14.15$ \\
\hline H. bispinis & Benthic & $74 \pm 5$ & $6.26 \pm 1.15$ \\
\hline A. depressiceps & Benthic & $111 \pm 58$ & $10.55 \pm 20.27$ \\
\hline
\end{tabular}


length (SL), body mass (M) and habitat of each species under study were different (Table 1).

The experiments were carried out with a photoperiod of 12 hours dark/12 hours light and the fish were not fed for at least 15 days before $\mathrm{VO}_{2 \mathrm{R}}$ measurements were obtained. Each specimen was acclimatised to $10^{\circ} \mathrm{C}( \pm 1)$ for 15 days inside individual stop flow respirometric chambers immersed in a tank of air-saturated seawater. The acclimatisation time was according to Shrode et al. (1982). After this period, the chamber was closed for 1-6 hours. The time that the camera remained closed was adjusted to make sure that the $\mathrm{O}_{2}$ saturation never descended below $80 \%$. Samples of $10 \mathrm{ml}$ of water were taken through a rubber cup with a syringe. The flexible material of the walls of the chamber allowed the volume compensation. Oxygen concentration was measured using a Clark-type polarographic electrode. Oxygen consumption data were taken 1-2 times a day until $\mathrm{O}_{2}$ consumption reached a stable routine level. The last 5 days of routine $\mathrm{O}_{2}$ consumption were used to calculate $\mathrm{VO}_{2 \mathrm{R}}$ by a mean.

Respirometric chambers were made of translucent plastic material, which prevented visual stimulation from external sources. Three types of respirometric chamber were used, according to the fish size. The biggest one, used with only one specimen of E. maclovinus, had a volume of 11 , about 10 times the fish. The second chamber type had a volume of $3.17 \mathrm{l}$, about 12 times the volume of the biggest $P$. magellanica used in this kind of chamber. The third type of chamber had a volume of $316 \mathrm{ml}$, about 30 times the volume of the biggest $A$. depressiceps used in this kind of chamber. In all cases, the volume of the chamber was found to be sufficient to allow spontaneous fish movements. The first and second types of chamber were furnished with transparent observation windows, regularly closed with a translucent lid during the experiments.

After $\mathrm{VO}_{2 \mathrm{R}}$ at $10^{\circ} \mathrm{C}$ was measured, the temperature was lowered by $1^{\circ} \mathrm{C}$ per day until a temperature of $4^{\circ} \mathrm{C}$ was reached. This temperature was maintained for ten days before $\mathrm{VO}_{2 \mathrm{R}}$ was determined. The same procedure was followed for the determination at $2^{\circ} \mathrm{C}$.

E. maclovinus did not tolerate prolonged confinement, so two groups of fish were used. One group of fishes was used in the experiment at $10^{\circ} \mathrm{C}$ and another at $4^{\circ} \mathrm{C}$ and $2^{\circ} \mathrm{C}$.

In order to compare species and $\mathrm{VO}_{2 \mathrm{R}}$ at different temperatures, the allometric scaling equations ( $\mathrm{Ln}$ $\mathrm{VO}_{2 \mathrm{R}}=\mathrm{a} \mathrm{Ln} \mathrm{M}+\mathrm{b}$ ) were obtained for each temper- ature and species. To perform a more general comparison, three inter-specific power equations were calculated for each temperature. For one of them, data from all species were used. For the other two, data obtained from benthic and pelagic and benthopelagic species were separated. The rate of $\mathrm{O}_{2}$ consumption was calculated for a standard fish of 50 g body mass and expressed by kilogram using the allometric equations mentioned above.

$\mathrm{Q}_{10}$ values were calculated from the variation in oxygen consumption of a standard fish of $50 \mathrm{~g}$ body mass and expressed by kilogram. The formula used was:

$$
\mathrm{Q}_{10}=\left(\mathrm{VO} 2_{\mathrm{R} 2} / \mathrm{VO} 2_{\mathrm{R} 1}\right)^{10 /(12-1)}(\text { Jobling, 1994). }
$$

\section{Statistics}

To test dependence between body mass and $\mathrm{VO}_{2 \mathrm{R}}$, an ANCOVA analysis was performed. Differences between slopes and elevations of regression lines were analysed to test the influence of temperature on $\mathrm{VO}_{2 \mathrm{R}}$ (Zar, 1984).

\section{RESULTS}

The results of oxygen consumption in the different species studied are synthesised in Figure 2. Oxygen consumption increased with both fish body mass and water temperature. Regression analysis showed that the $\mathrm{VO}_{2 \mathrm{R}}$ increased significantly with fish body mass $(\mathrm{M})(p<0.05)$ for all temperatures and for all species. The same statistically significant relationship was found for all species considered together and for the active and sluggish groups (Table 2; Fig. 2).

A specific response was obtained when temperature was reduced from 4 to $2^{\circ} \mathrm{C}$ (Table 2): the decrease in $\mathrm{VO}_{2 \mathrm{R}}$ was small in the most active species (E. maclovinus and P. magellanica), whereas in the other-more sedentary-species the decrease was more pronounced.

A decrease in temperature from 10 to $4{ }^{\circ} \mathrm{C}$ caused significant differences $(p<0.05)$ in the elevation of all regressions that describe $\mathrm{VO}_{2 \mathrm{R}}$ response, except for $P$. sima. Reduction of temperature from 4 to $2^{\circ} \mathrm{C}$ produced significant differences in $\mathrm{VO}_{2 \mathrm{R}}$ only in $P$. sima and $H$. bispinis, while in the other species it produced a non-significant reduction. Differences between elevations of the 10 and $2{ }^{\circ} \mathrm{C}$ curves were significant in all species. 

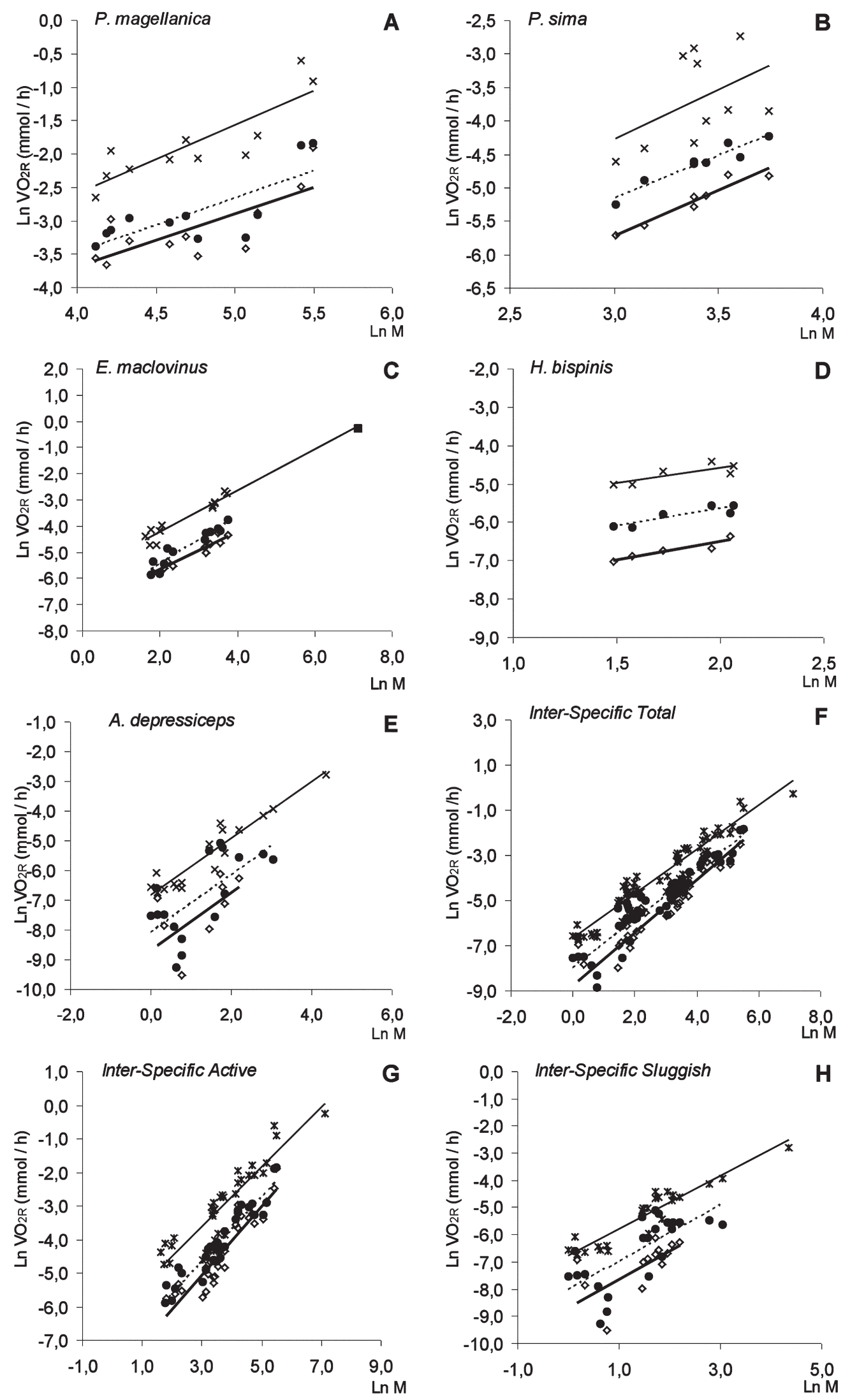

FIG. 2. - Relationship between the logarithm of body mass in $\mathrm{g}(\mathrm{Ln} \mathrm{M})$ and the logarithm of the routine metabolic rate in $\mathrm{mmol} \mathrm{O}_{2} / \mathrm{h}$, $(\mathrm{Ln}$ $\left.\mathrm{VO}_{2 \mathrm{R}}\right)$ at different experimental temperatures $\left(x=10^{\circ} \mathrm{C} ; \bullet=4^{\circ} \mathrm{C} ; \diamond=2^{\circ} \mathrm{C}\right)$. A - E) Subantarctic teleosts used in present work $(\boldsymbol{\square}$ in E. maclovinus out of ANCOVA analysis). F) Interspecific total. G) Inter-specific active. H) Inter-specific sluggish. 
TABLE 2. - Allometric scaling equation for species and temperature. Differences between elevation of regression lines are exposed in the Elev column. Routine Oxygen Consumptions $\left(\mathrm{VO}_{2 \mathrm{R}}\right)$ for a standard $50 \mathrm{~g}$ fish $(\mathrm{mmol} \mathrm{O} / \mathrm{h} / \mathrm{kg})$. Values of $\mathrm{R}^{2}$ are shown.

\begin{tabular}{|c|c|c|c|c|c|c|}
\hline Species & $\mathrm{T}\left({ }^{\circ} \mathrm{C}\right)$ & $\mathrm{n}$ & $\begin{array}{l}\text { Scaling Equation } \\
\text { Ln VO }_{2 \mathrm{R}}=\end{array}$ & Elev & $\begin{array}{c}\mathrm{VO}_{2 \mathrm{R}} \\
\mathrm{mmol} / \mathrm{h} / \mathrm{kg}\end{array}$ & $\mathrm{R}^{2}$ \\
\hline P. magellanica & $\begin{array}{l}10 \\
4 \\
2\end{array}$ & $\begin{array}{l}11 \\
11 \\
11\end{array}$ & $\begin{array}{c}1.029 \operatorname{Ln} \mathrm{M}-6.7163 \\
0.8135 \mathrm{Ln} \mathrm{M}-6.737 \\
0.7913 \mathrm{Ln} \mathrm{M}-6.8565\end{array}$ & $\begin{array}{l}\mathrm{a} \\
\mathrm{b} \\
\mathrm{b}\end{array}$ & $\begin{array}{l}1.36 \\
0.57 \\
0.47\end{array}$ & $\begin{array}{l}0.73 \\
0.57 \\
0.55\end{array}$ \\
\hline P. sima & $\begin{array}{l}10 \\
4 \\
2\end{array}$ & $\begin{array}{c}10 \\
8 \\
7\end{array}$ & $\begin{array}{l}\text { 1.4684 Ln M - } 8.6727 \\
1.2814 \text { Ln M - } 9.0024 \\
1.3547 \text { Ln M - } 9.7871\end{array}$ & $\begin{array}{l}\mathrm{a} \\
\mathrm{b} \\
\mathrm{c}\end{array}$ & $\begin{array}{l}1.08 \\
0.37 \\
0.23\end{array}$ & $\begin{array}{l}0.21 \\
0.91 \\
0.92\end{array}$ \\
\hline E. maclovinus & $\begin{array}{l}10 \\
4 \\
2\end{array}$ & $\begin{array}{l}13 \\
12 \\
10\end{array}$ & $\begin{array}{l}0.7862 \text { Ln M - } 5.7888 \\
0.9132 \text { Ln M - } 7.2614 \\
0.7272 \text { Ln M - } 7.1057\end{array}$ & $\begin{array}{l}\mathrm{a} \\
\mathrm{b} \\
\mathrm{b}\end{array}$ & $\begin{array}{l}1.33 \\
0.50 \\
0.28\end{array}$ & $\begin{array}{l}0.97 \\
0.91 \\
0.92\end{array}$ \\
\hline H. bispinis & $\begin{array}{l}10 \\
4 \\
2\end{array}$ & $\begin{array}{l}6 \\
6 \\
5\end{array}$ & $\begin{array}{c}0.8056 \text { Ln M }-6.1847 \\
0.8922 \text { Ln M }-7.436 \\
0.964 \text { Ln M }-8.4283\end{array}$ & $\begin{array}{l}\mathrm{a} \\
\mathrm{b} \\
\mathrm{c}\end{array}$ & $\begin{array}{l}0.96 \\
0.39 \\
0.19\end{array}$ & $\begin{array}{l}0.68 \\
0.80 \\
0.88\end{array}$ \\
\hline A. depressiceps & $\begin{array}{l}10 \\
4 \\
2\end{array}$ & $\begin{array}{l}14 \\
13 \\
7\end{array}$ & $\begin{array}{l}0.9504 \text { Ln M - } 6.8193 \\
0.9569 \text { Ln M - } 8.0607 \\
0.9605 \text { Ln M }-8.6686\end{array}$ & $\begin{array}{l}\mathrm{a} \\
\mathrm{b} \\
\mathrm{b}\end{array}$ & $\begin{array}{l}0.90 \\
0.27 \\
0.15\end{array}$ & $\begin{array}{l}0.89 \\
0.45 \\
0.33\end{array}$ \\
\hline $\begin{array}{l}\text { Inter-Specific } \\
\text { Total }\end{array}$ & $\begin{array}{l}10 \\
4 \\
2\end{array}$ & & $\begin{array}{c}0.9843 \mathrm{Ln} \mathrm{M}-6.6778 \\
1.06 \mathrm{Ln} \mathrm{M}-7.9919 \\
1.1662 \mathrm{Ln} \mathrm{M}-8.735\end{array}$ & & $\begin{array}{l}1.18 \\
0.43 \\
0.31\end{array}$ & $\begin{array}{l}0.92 \\
0.86 \\
0.89\end{array}$ \\
\hline $\begin{array}{l}\text { Inter-Specific } \\
\text { Active }\end{array}$ & $\begin{array}{l}10 \\
4 \\
2\end{array}$ & & $\begin{array}{l}0.8901 \text { Ln M - } 6.2661 \\
0.9545 \text { Ln M - } 7.5172 \\
1.0256 \text { Ln M - } 8.1422\end{array}$ & & $\begin{array}{l}1.28 \\
0.46 \\
0.32\end{array}$ & $\begin{array}{l}0.83 \\
0.90 \\
0.86\end{array}$ \\
\hline $\begin{array}{l}\text { Inter-Specific } \\
\text { Sluggish }\end{array}$ & $\begin{array}{l}10 \\
4 \\
2\end{array}$ & & $\begin{array}{l}0.9755 \operatorname{Ln~M}-6.7603 \\
1.0381 \text { Ln M - 8.0354 } \\
1.0378 \text { Ln M - 8.6893 }\end{array}$ & & $\begin{array}{l}1.05 \\
0.38 \\
0.20\end{array}$ & $\begin{array}{l}0.88 \\
0.50 \\
0.42\end{array}$ \\
\hline \multicolumn{3}{|c|}{ Intra-Specific b mean } & 0.99 & & & \\
\hline
\end{tabular}

TABLE 3. $-\mathrm{Q}_{10}$ values obtained of changes in temperature $2-10^{\circ} \mathrm{C}$ and $4-10^{\circ} \mathrm{C} . \mathrm{Q}_{10}$ were calculated using oxygen consumption for a $50 \mathrm{~g}$ standard fish by $\mathrm{kg}$.

\begin{tabular}{lccccc}
\hline Thermic range $\left({ }^{\circ} \mathrm{C}\right)$ & P. magellanica & P. sima & E. maclovinus & H. bispinis & A. depressiceps \\
\hline $2-10$ & 3.81 & 7.04 & 6.91 & 7.60 & 9.63 \\
$4-10$ & 4.22 & 6.00 & 5.08 & 4.56 & 7.61 \\
\hline
\end{tabular}

In the analyses of the scaling equations, separately for each species or after pooling data according to the habitat, the active species (E. maclovinus, P. sima, P. magellanica) showed a consistent tendency to reach higher values than the sluggish species (A. depressiceps, H. bispinis) for each temperature (Fig. 2, Table 2). Except for P. magellanica, in all the studied species the $\mathrm{Q}_{10}$ values for the 2$10^{\circ} \mathrm{C}$ interval were higher than for $4-10^{\circ} \mathrm{C}$ (Table 3 ). The highest values of $\mathrm{Q}_{10}$ were reached by the nonnotothenioid sluggish $A$. depressiceps.

\section{DISCUSSION}

The experimental temperatures applied in this study $\left(10-2^{\circ} \mathrm{C}\right)$ with Subantarctic notothenioids fills the discontinuity between metabolic responses of Antarctic nototheniods and temperate percifoms (Fig. 3). This gap constitutes a problem mentioned by Clarke and Johnston (1999), and originates in the inability of polar fish to live at temperatures higher than $6^{\circ} \mathrm{C}$ and the lethal effect of temperatures close to $0^{\circ} \mathrm{C}$ for temperate perciform fishes. The highest experimental temperature used in this study $\left(10^{\circ} \mathrm{C}\right)$ represents the maximum to which some Subantarctic species are exposed during a "regular summer". Oxygen consumption at this temperature showed a noticeable increase, reaching values two or three times greater than the "regular winter" $\left(4^{\circ} \mathrm{C}\right)$ conditions (Fig. 3 and Table 2).

Oxygen consumption rate, like many other metabolic processes, is largely related to body mass, following the general power equation $\mathrm{VO}_{2 \mathrm{R}}=\mathrm{a} \mathrm{M}^{\mathrm{b}}$, 


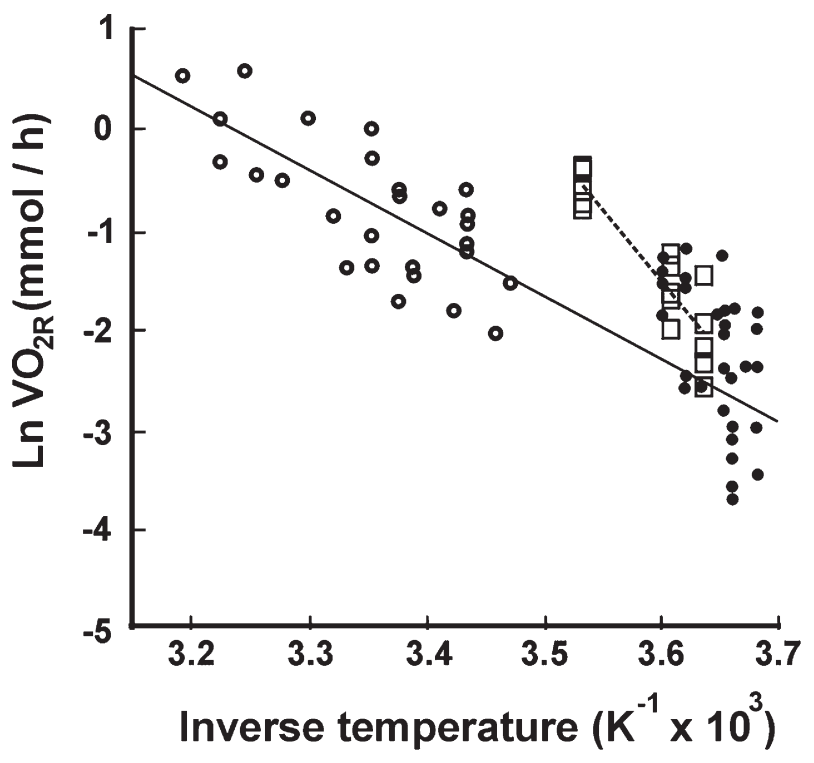

FIG. 3. - Arrhenius plot of $\mathrm{VO}_{2 \mathrm{R}}$ of Subantarctic perciforms ( $\square$; present work), Antarctic notothenioids $(\bullet)$ and warmer water perciforms ( $\bigcirc$ non notothenioids). Oxygen consumption values standardised for a $50 \mathrm{~g}$ fish. Regression line (-) fitted to warmer water perciforms. Regression line (---) fitted to Subantarctic perciforms (present work). Adapted from Clarke and Johnston (1999)

(Jobling, 1993; West et al., 1997). Clarke and Johnston (1999) reviewed this subject, analysing the results of 138 publications on relationships between temperature, body size and routine oxygen consumption in 69 species of fishes. The slope (b) of specific equations varied between 0.3 and 1.2 , with a mean value of 0.79 . In our study values of $b$ for active, sluggish or all the species together at each experimental temperature (Table 2) were higher than the mean obtained by Clarke and Johnston (1999) but within the range of distribution of their data.

$\mathrm{VO}_{2 \mathrm{R}}$ values of Subantarctic species of this study were correlated with habitat (Table 2). Paranotothenia magellanica has the highest oxygen consumption rates at all experimental temperatures. This species was reported as highly mobile (Moreno and Jara, 1984) and shows swimming movements in aquaria more frequently than the other Subantarctic species studied in our laboratory (pers. obs.).

$\mathrm{VO}_{2 \mathrm{R}}$ values of $E$. maclovinus are similar to $P$. magellanica values at 10 and $4{ }^{\circ} \mathrm{C}$ but drop to a level similar to that observed in the less active species at $2^{\circ} \mathrm{C}$ (Table 2). An explanation of this phenomenon could be that $P$. magellanica, more active than $E$. maclovinus, could maintain a higher $\mathrm{O}_{2}$ consumption at low temperatures. On the other hand, the authors saw that many specimens of E. maclovinus showed signs of low tolerance to the confinement in respirometric chambers, which can cause a high $\mathrm{VO}_{2}$, espe- cially at summer temperatures. However, $\mathrm{O}_{2}$ consumption in this species remained stable once routine values were reached, after the initial stress period. Although oxygen consumption of $H$. bispinis and $A$. depressiceps was virtually identical at $10^{\circ} \mathrm{C}$, a higher $\mathrm{VO}_{2 \mathrm{R}}$ was calculated for the Harpagiferidae at 4 and $2^{\circ} \mathrm{C}$. This species is more active than A. depressiceps in both aquaria and the rocky intertidal zone, its natural environment (pers. obs.). This correlation between habitat and $\mathrm{VO}_{2 \mathrm{R}}$ was also reported for other notothenioids by Morris and North (1984) and Zimmermann (1997), but a correspondence between temperature or habitat is not observed for the specific mass exponent $b$ (Table 2).

At both temperature ranges, $2-10$ and $4-10^{\circ} \mathrm{C}$, $\mathrm{Q}_{10}$ values of P. magellanica were the lowest, while A. depressiceps reached the highest values (Table 3 ). $A Q_{10}$ with a similar value, around 9 , has been calculated for the Antarctic eelpout Pachycara brachycephalum at $3-9^{\circ} \mathrm{C}$ (Hardewig et al., 1998). It is therefore possible to assume a greater effect of temperature limiting the oxygen consumption for the sluggish Subantarctic eelpout in this thermal range. This difference in reactions to changes in temperature would be predictable if a strong influence of habitat in $\mathrm{VO}_{2}$ consumption were present. However, high values of $\mathrm{Q}_{10}$ were observed in the other species used in this study. Another explanation is that in this work the fish did not show compensation responses during the acclimation time. When $\mathrm{VO}_{2}$ became stable, it persisted for longer than 15-20 days. However, if this time was too short to allow the expression of compensation processes, an overreaction could be expected in the $\mathrm{Q}_{10}$ values.

The $V O_{2 R}$ values of Subantarctic teleosts obtained in this study (Fig. 3) are higher than the general regression line drawn up by Clarke and Johnston (1999) with non-notothenioid warm water fish. Although data used by Clarke and Johnston were obtained under resting conditions, the difference is negligible at 4 and $2^{\circ} \mathrm{C}$. This small difference from the resting data at winter temperatures could show an effective acclimation process to winter temperatures in the time that the animals had available to carry out this process.

The present values obtained at $10^{\circ} \mathrm{C}$ are considerably higher than the regression line obtained by Clarke and Johnston (1999) for temperate perciforms. A possible explanation for Subantarctic notothenioid species could be the hypothesis of Pörtner et al. (2000) and Pörtner (2002). These authors relate the reduction in energy demand and 
high activation energies of mitochondrial enzymes involved in the oxygen demand with the low metabolic rates in stenothermal fish adapted to cold. In the case of Subantarctic notothenioids, kinematic barriers could be established by the environmental temperatures, producing an extremely high value of $\mathrm{VO}_{2 \mathrm{R}}$ at $10^{\circ} \mathrm{C}$ (Fig. 3). Another reason for this overreaction at $10^{\circ} \mathrm{C}$ could be an increase in the corporal movement caused by high temperature. Again, an appropriate quantification of activity could be necessary to determine resting $\mathrm{O}_{2}$ consumption.

Our results are not conclusive, but the wide range of responses obtained suggests an evolutionary adjustment to the variable Subantarctic environment and an increase in width of the tolerance window over the ancestral thermal range. We can conclude that the metabolic rates of the studied species of Subantarctic notothenioids do not show MCA in the Krogh (1916) definition sensu stricto. However, an overreaction in the metabolic responses of notothenioids at Subantarctic summer temperatures could be the expression of the metabolic adjustment of the more stenothermal Antarctic ancestors to cold temperatures.

\section{ACKNOWLEDGEMENTS}

This study was supported by a CONICET scholarship ( $\mathrm{N}^{\circ}$ 0678), an Agencia Nacional de Promoción Científica y Tecnológica grant (PEI N $042 / 98$ 047/98), a Fundación Antorchas-British Council grant (1998-2001), an Antorchas grant (Proy 13817/4) and a U.N.P.S.J.B. grant (P.I.N. 256 / SCT 035/98).

\section{REFERENCES}

Clarke, A. - 1991. What is cold adaptation and how should we measure it? Amer. Zool., 31: 81-92.

Clarke, A. and N.M. Johnston. - 1999. Scaling of metabolic rate with body mass and temperature in teleost fish. J. Anim. Ecol., 68: 893-905.

Crockett, E.L. and B.D. Sidell. - 1990. Some pathways of energy metabolism are cold adapted in Antarctic fishes. Physiol. Zool., 63: 472-488.

Hardewig, I., P.L.M. van Dijk and H.O. Pörtner. - 1998. High-energy turnover at low temperatures: recovery exhaustive exercise in Antarctic and temperate eelpouts. Am. J. Physiol., 274: R1789-R1796.

Holeton, G.F. - 1974. Metabolic cold adaptation of polar fish: fact or artifact? Physiol. Zool. 47: 137-152. In: Eastman, J. - 1993.
Antarctic fish biology, evolution in a unique environment. Academic Press, San Diego.

Jobling, M. - 1993. Bioenergetics; feed intake and energy partitioning. In: J.C. Rankin and F.B. Jensen (eds.), Fish ecophysiology, pp. 1-44., Chapman and Hall, London.

Jobling, M. - 1994. Fish bioenergetics. Chapman and Hall, London.

Johnston, I.A., J. Calvo, H. Guderley, D. Fernández and L. Palmer. - 1998. Latitudinal variation in the abundance and oxidative capacities of muscle mitochondria in perciform fishes. J. Exp. Biol., 201: 1-12.

Krogh, A. - 1916. The respiratory exchange of animals and man. Longmans-Green (eds.), London. pp. 1-173. Fide: Steffensen, J.F., P.G. Bushnell and H. Schurmann. - 1994. Oxygen consumption in four species of teleosts from Greenland: no evidence of metabolic cold adaptation. Polar Biol., 14, 49-54

Moreno, C. and H. Jara. - 1984. Ecological studies on fish fauna associated with Macrocystis pyrifera belts in the south Fueguian Island, Chile. Mar. Ecol. Prog. Ser., 15: 99-107.

Morris, D.J. and A.W. North. - 1984. Oxygen consumption of five species of fish from South Georgia. J. Exp. Mar. Biol. Ecol., 78: 75-86.

Peck, L.S. - 2002. Ecophysiology of Antarctic marine ectotherms: limits to life. Polar. Biol., 25: 35-40.

Pörtner, H.O. - 2002. Climate variations and the physiological basis of temperature dependent biogeography: systemic to molecular hierarchy of thermal tolerance in animals. Comp. Biochem. Phys. A: Comp. Physiol., 132: 739-761.

Pörtner, H.O., P.L.M. Van Dijk, I. Hardewig and A. Sommer. 2000. Levels of metabolic cold adaptation: tradeoffs in eurythermal and stenothermal ectotherms. In: W. Davison and C. Howard Williams (eds.), Antarctic ecosystems: Models for wider ecological understanding. Caxton, Christchurch.

Schmidt-Nielsen, K. - 1984. Scaling: Why is animal size so important?, Cambridge University Press. London.

Scholander, P.F., W. Flagg, V. Walters and L. Irving. - 1953. Climatic adaptation in arctic and tropical poikilotherms. Physiol. Zool., 26: 67-92.

Shrode, J.B., K.E. Zerba and J.S. Stephens. - 1982. Ecological significance of temperature tolerance and preference of some inshore California fishes. Trans. Amer. Fish. Soc., 111(1): 45-51.

Sidell, B.D. -2000 . Life at body temperatures below $0^{\circ} \mathrm{C}$ : the physiology and biochemistry of Antarctic fishes. Gravitational and Space Biological Bulletin, 13: 25-34.

Somero, G.N. - 1991. Biochemical mechanisms of cold adaptation and stenothermality in Antarctic fish. In: G. di Prisco, B. Maresca and B. Tota (eds.), Biology of Antarctic fish, pp. 232247. Springer-Verlag. Berlin.

Steffensen, J.F., P.G. Bushnell and H. Schurmann. - 1994. Oxygen consumption in four species of teleosts from Greenland: no evidence of metabolic cold adaptation. Polar Biol., 14: 49-54.

Steffensen, J.F. - 2002. Metabolic cold adaptation of polar fish based on measurements of aerobic oxygen consumption: fact or artefact? Artefact! Comp. Biochem. Phys. A: Comp. Physiol., 132: 789-795.

Torres, J.J. and G.N. Somero. - 1988a. Metabolism, enzymic activities and cold adaptation in Antarctic mesopelagic fishes. Mar. Biol., 98: 169-180.

Torres, J.J. and G.N. Somero. - 1988b. Vertical distribution and metabolism in Antarctic mesopelagic fishes. Comp. Biochem. Physiol., 90: 521-528.

West, G.B., J.H. Brown and B.J. Enquist. - 1997. A general model for the origin of allometric scaling laws in biology. Science, 276: 122-126.

Willmer, P., G. Stone and I. Johnston. - 2000. Environmental physiology of animals. MPG Books, Cornwall.

Wohlschlag, D.E. - 1960. Metabolism of an Antarctic fish and the phenomenon of cold adaptation. Ecology 41: 287-292.

Zar, J.H. - 1984. Biostatistical analysis. Prentice-Hall International, Inc., New Jersey.

Zimmermann, C. - 1997. On the ecology of Arctic and Antarctic fish: activity, sensory capabilities and behavior. Ber. Polarforsch., 231: 1-137. 
